\title{
The Clinical Implications of Hepatic Enzymes in Metabolically Healthy Obese Men
}

\author{
Kyung-A Shin \\ Department of Clinical Laboratory Science, Shinsung University, Dangjin, Korea
}

\section{대사적으로 건강한 비만남성에서 간 효소의 임상적 의의}

\author{
신경아 \\ 신성대학교 임상병리과
}

\begin{abstract}
Increased hepatic enzymes are associated with insulin resistance, metabolic complications, and type 2 diabetes mellitus. Metabolically healthy obese $(\mathrm{MHO})$ phenotype is not accompanied by metabolic complications and maintains insulin sensitivity, despite excessive body fat. The purpose of this study was to evaluate the clinical implications of hepatic enzymes in MHO men. The diagnostic criteria for MHO were based on NCEP-ATP III and obesity in adults was defined using WHO Asian-Pacific criteria. We used the data from 9,683 obese men aged between 20 and 70 years. The subjects were divided into three groups according to the diagnostic criteria: The metabolically healthy non-obese ( $M H N O, N=2,878$ ), metabolically healthy obese ( $M H O$, $\mathrm{N}=5,427$ ), and metabolically abnormal obese ( $\mathrm{MAO}, \mathrm{N}=1,378)$. Obesity criteria were classified according to the standards set forth by WHO Asia-Pacific Criteria. AST, ALT, and GGT were significantly lower in the $\mathrm{MHO}$ group than in the $\mathrm{MAO}$ group ( $p<0.001$, respectively). However, the hepatic enzyme levels were higher in the MHO group than in the MHNO group $(p<0.001)$. Liver enzymes were associated with metabolic syndrome risk factors. Waist circumference, fasting glucose, total cholesterol, triglyceride, and $\mathrm{HDL}-\mathrm{C}$ were risk factors for metabolic syndrome affecting liver enzymes. In conclusion, hepatic enzymes were found to predict metabolic abnormalities in metabolically healthy obese men.
\end{abstract}

Key words: Metabolically healthy obese, Metabolic complication, Hepatic enzyme

This is an Open Access article distributed under the terms of the Creative Commons Attribution Non-Commercial Licens (http://creativecommons.org/licenses/by-nc/4.0) which permits unrestricted non-commercial use, distribution, and reproduction in any medium, provided the original work is properly cited.

Copyright @ 2017 The Korean Society for Clinical Laboratory Science. All rights reserved.
Corresponding author: Kyung-A Shin Department of Clinical Laboratory Science, Shinsung University, 1 Daehak-ro, Jeongmi-myeon, Dangjin 31801, Korea Tel: 82-41-350-1408 Fax: 82-41-350-1355

E-mail: mobitz2@hanmail.net

Received: June 29, 2017

Revised: July 27, 2017

Accepted: August 3, 2017
서론

비만은 제2형 당뇨병, 고혈압, 이상지질혈증, 심혈관질환, 비 알코올성 지방증(non-alcoholic steatosis), 수면 무호흡증, 근 골격계 질환 및 악성종양의 위험 요인으로 인식되고 있다[1-9]. 비만인 경우 과도한 에너지 섭취로 인해 지방 조직뿐만 아니라 간, 골격근, 췌장, 심장세포 등 비지방 조직에 중성지방이 축적 되는 이소성 지방(ectopic fat)의 과잉현상이 나타난다[10]. 이 러한 이소성 지방은 인슐린 저항성과 염증반응을 유도하며, 비
만인의 대사장애를 일으키는 원인이 될 수 있다[11]. 그러나 임 상 및 역학연구에 따르면 비만과 과체중이 반드시 심혈관계를 포함하는 만성질환의 유병률 및 사망률 증가와 관련이 있는 것 은 아니다[12,13]. 이와 관련하여 대사적으로 건강한 비만인 (metabolically healthy obese, $\mathrm{MHO}$ )은 대사적 합병증과 심 혈관계 기능이상을 동반하지 않으며, 과도한 체지방에도 불구 하고 인슐린 감수성을 유지하는 비만의 표현형으로 제시된다 [14]. 대사적으로 유리한 $\mathrm{MHO}$ 를 유발하는 기전에 대해서는 알 려진 바가 없으나, 예비증거로 내장지방 축적, 출생시 체중, 지 
방세포 크기 및 지방세포 분화의 유전자 발현 차이가 원인으로 추정된다[14].

$\mathrm{MHO}$ 은 미국 비만인구의 30 40\%를 차지하며[6,15], 우리 나라의 경우 국민건강영양조사 자료를 근거로 전체 인구의 $15.2 \%$, 비만인구의 $47.9 \%$ 가 $\mathrm{MHO}$ 로 분류된다고 평가하였다 [16]. MHO와 관련된 연구에서 대사적으로 이상이 있는 비만인 (metabolically abnormal obese, $\mathrm{MAO}$ )과 비교해 $\mathrm{MHO}$ 는 신 체적으로는 유사한 비만 체형일지라도 피하지방에는 차이가 없 으나, 내장지방 축적 정도는 적은 특징을 가지고 있다[17]. 또한 $\mathrm{MAO}$ 와 비교해 $\mathrm{MHO}$ 는 혈압, 복부비만, 지질대사 이상 정도가 낮으며[14], 제2형 당뇨병 및 심혈관계 질환의 위험이 감소하는 것으로 보고된다[15].

한편, Messier 등[2]의 연구에 의하면 $\mathrm{MAO}$ 보다 $\mathrm{MHO}$ 에서 아스파테이트아미노전이효소(aspartic aminotransferase, AST), 알라닌아미노전이효소(alanin aminotransferase, ALT), 알칼 리인산분해효소(alkaline phosphatase, ALP)와감마글루타밀 전이효소(gamma glutamyl transferase, GGT)등 간 효소치가 낮은 것으로 보고하였다. 내장 및 근육내 지방과는 독립적으로 간의 지방축적은 인슐린 저항성의 중심적 역할을 하는데, 높은 간 효소치는 간에 과도한 지질 침전을 반영한다[11,18]. 이와같 은 선행연구들은 주로 폐경기[1-4] 및 일반 여성[5], 청소년[11] 을 대상으로 한 연구들이며, 국내연구의 경우 국민건강영양조 사 자료를 이용하여 비만 표현형과 건강행위간의 관련성을 보 고하고 있다[16]. 그러나 $\mathrm{MHO}$ 의 정확한 범위에 대해서는 진단 기준이나 인종, 연령 및 신체활동 수준이 영향을 미치는 것으로 알려져 있으며[11], 남성 아시아인의 특성을 반영한 비만 표현 형에 따른 간 효소의 차이를 비교한 연구는 부족한 실정이다.

그러므로 이 연구에서는 비만남성을 대상으로 NCEP-ATP III (National Cholesterol Education Programme Adult Treatment Panel III) 진단기준을 반영하여 대사이상 유무에 따 라 $\mathrm{MHO}$ 와 $\mathrm{MAO}$ 군으로 분류하여 간 효소의 차이를 알아보고 대사적으로 건강한 비만남성에서 간 효소가 대사적 이상을 예 측할 수 있는 지표인지 그 임상적 의의를 확인하고자 하였다.

\section{대상 및 방법}

\section{1. 연구 대상}

이 연구의 대상자는 일개 종합병원에서 2014년 1월부터 2016년 12월까지 건강검진 수진자 중 20세 이상 70세 이하의 남성을 대상으로 하였다. 전체 대상자 13,652 명 중에서 해당자 료에 결측치가 있거나 B형 간염보균자 및 C형 간염양성자, 간경
화, 알코올성 간질환자, 간암 등 간질환자 3,969명을 제외하고 대사적으로 건강한 정상체중군(metabolically healthy non obese, MHNO), 대사적으로 건강한 비만군(metabolically healthy obese, $\mathrm{MHO}$ ), 대사적으로 이상이 있는 비만군 (metabolically abnormal obese, MAO)에 해당하는 9,683명 을 최종 연구 대상자로 선정하였다. 최종 연구 대상자의 병력 및 약물복용에 대한 자료는 자기기입식 설문조사로 얻었으며, 경 기지역 종합병원 생명윤리 심의위원회(Institutional Review Board, IRB)의 승인을 받은 후 연구를 진행하였다(IRB No: D-1207-002-0102).

\section{2. 연구방법}

\section{1) 대사증후군 및 비만 진단기준}

NCEP-ATP III 의 기준에 따라 (1) 중성지방 $150 \mathrm{mg} / \mathrm{dL}$ 이상, (2)HDL-콜레스테롤 남성 $40 \mathrm{mg} / \mathrm{dL}$ 미만, (3)수축기와 이완기 혈압 130/85 mmHg 이상 또는 고혈압 약 복용, (4) 공복혈당 $100 \mathrm{mg} / \mathrm{dL}$ 이상 또는 당뇨 치료제 복용, (5)허리둘레 남성 102 $\mathrm{cm}$ 이상의 5 가지 기준 중 3 개 이상인 경우 대사적으로 이상이 있는 군, 2 개 이하인 경우 대사적으로 건강한 군으로 정의하였 다[19]. 다만 복부비만의 경우 아시아인의 기준인 $90 \mathrm{~cm}$ 이상 을 적용하였다[20]. 또한 비만 진단기준은 $\mathrm{WHO}$ 에서 제시하는 아시아인의 기준인 체질량지수(body mass index, BMI) 25 $\mathrm{kg} / \mathrm{m}^{2}$ 이상인 경우 비만으로, $18.5 \sim 22.9 \mathrm{~kg} / \mathrm{m}^{2}$ 를 정상체중 으로 정의하였다[20]. 이러한 위의 진단기준에 따라 대사적으 로 건강한 정상체중군(metabolically healthy non-obese, $\mathrm{MHNO}, \mathrm{N}=2,878$ ), 대사적으로 건강한 비만군(metabolically healthy obese, $\mathrm{MHO}, \mathrm{N}=5,427$ ), 대사적으로 이상이 있는 비 만군(metabolically abnormal obese, $\mathrm{MAO}, \mathrm{N}=1,378$ )의 세 군으로 분류하였다[21].

\section{2) 혈압 및 신체계측}

수축기와 이완기 혈압은 안정 상태에서 수은 혈압계로 측정 하였으며, 2회 측정하여 평균값으로 제시하였다. 또한 체성분 분석기 Inbody 720 (Seoul, Korea)을 이용하여 신장과 체중을 측정하였으며, BMI는 체중 $(\mathrm{kg}) \div$ 키의 제곱 $\left(\mathrm{m}^{2}\right)$ 으로 산출하였 다. 허리둘레는 $\mathrm{WHO}$ 에서 제시한 방법에 따라 양 발을 $25 \sim 30$ $\mathrm{cm}$ 벌린 후 숨을 내쉰 상태에서 갈비뼈 맨 아랫부분과 골반 상 부 사이의 중간 부위를 측정하였으며, 엉덩이 둘레는 엉덩이의 가장 높은 부분을 줄자로 측정하였다. 


\section{3) 혈액분석}

혈액검사는 8시간 이상 금식 후 공복상태에서 오전에 상완정 맥(antecubital vein)에서 채혈 후 측정하였다. TBA-200FR $\mathrm{NEO}$ (Toshiba, Tokyo, Japan) 생화학 자동분석기로 AST, ALT, GGT, 총콜레스테롤, 고밀도 지단백 콜레스테롤(high density lipoprotein-cholesterol, HDL-C), 저밀도 지단백 콜레스테롤 (low density lipoprotein-cholesterol, LDL-C), 중성지방, 공 복혈당, 요산, 고민감도 C-반응성 단백(high sensitivity C-reactive protein, hs-CRP)을 측정하였으며, 고민감도 C-반응성 단백은 TIA (turbidimetric immunoassay) 면역비탁법의 원리 로 측정하였다. 당화헤모글로빈(hemoglobin A1c, HbA1c)은 EDTA tube에 채혈한 전혈 검체로 Variant II (Bio Rad, CA, USA) 장비를 이용하여 고성능액체크로마토그래피법(high performance liquid chromatography, HPLC)의 원리로 측정 하였다. 또한 인슐린 농도는 전기화학발광면역분석법(electrochemiluminescence immunoassay, ECLIA)의 원리로 Modular Analytics E170 (Roche, Mannheim, Germany)장비 로 측정하였다. HOMA-IR (homeostasis model assessment-insulin resistance)은 인슐린 저항성을 간접적으로 반영 하는 지표로서 공복 시 인슐린과 혈당치를 이용하여 (공복 시 인 슐린 $\mu \mathrm{IU} / \mathrm{mL} \times$ 공복 시 혈당 $\mathrm{mg} / \mathrm{dL}) / 405$ 공식으로 계산하였 다[22].

\section{3. 통계분석}

이 연구는 Windows SPSS 21.0 (IBM, Armonk, USA) 통계 프로그램을 이용하여 자료를 처리하였으며, 모수적 통계방법 은 평균과 표준편차, 비모수적 통계방법은 빈도와 \%로 제시하 였다. $\mathrm{MHNO}, \mathrm{MHO}, \mathrm{MAO}$ 군의 집단간 임상적 및 생화학적 지 표, 간 효소 차이를 비교하기 위해 일원분산분석(one way analysis of variance, ANOVA)을 실시하였으며, 통계적으로 차이가 있는 경우 사후검증으로 bonferroni 방법을 적용하였 다. 또한 집단간 대사증후군 위험요인의 빈도 차이를 비교하기 위해 카이제곱 검정(chi-square test)을 시행하였다. 대사증후 군 위험요인과 간 효소의 상관관계를 알아보기 위해 피어슨의 적률상관분석(pearson correlation coefficient)을 실시하였 으며, 연령을 보정한 후 중다회귀분석(multiple regression analysis)을 통해 간 효소에 영향을 미치는 위험요인을 예측하 였다. 이 연구결과의 통계적 유의수준은 $p$ 값 0.05 미만으로 설 정하였다.

\section{결 과}

\section{1. 대상자의 집단간 임상적 및 생화학적 특성 차이}

연구 대상자를 비만과 대사증후군 유무에 따라 $\mathrm{MHNO}$, $\mathrm{MHO}, \mathrm{MAO}$ 의 세 군으로 나누어 집단간 임상적 및 생화학적 특 성의 차이를 비교한 결과는 Table 1과 같다. 연령은 $\mathrm{MHNO}$ 군과 $\mathrm{MHO}$ 군보다 $\mathrm{MAO}$ 군에서 높았다 $(p<0.001)$. 신장은 $\mathrm{MHO}$ 군보 다 $\mathrm{MHNO}$ 와 $\mathrm{MAO}$ 군이 컸다 $(p=0.001)$. 체중, $\mathrm{BMI}$, 허리둘레, 엉덩이 둘레는 $\mathrm{MHNO}$ 군보다 $\mathrm{MHO}$ 와 $\mathrm{MAO}$ 군이 높았으며, $\mathrm{MHO}$ 군보다 $\mathrm{MAO}$ 군이 높았다(각각 $p<0.001$ ). 수축기와 이완 기 혈압은 $\mathrm{MHNO}$ 군보다 $\mathrm{MHO}$ 와 $\mathrm{MAO}$ 군이 높았으며, $\mathrm{MHO}$ 군보 다 $\mathrm{MAO}$ 군이 높았다(각각 $p<0.001$. 생화학적 지표인 총콜레스 테롤은 $\mathrm{MHNO}$ 군보다 $\mathrm{MHO}$ 와 $\mathrm{MAO}$ 군이 높았으며 $(p<0.001)$, 중성지방, 공복혈당, 요산, hs-CRP, HbA1c, 인슐린, HOMA-IR 은 $\mathrm{MHNO}$ 군보다 $\mathrm{MHO}$ 와 $\mathrm{MAO}$ 군에서 높았으며, $\mathrm{MHO}$ 군보다 $\mathrm{MAO}$ 군이 높게 나타났다(각각 $p<0.001)$. LDL-C은 MHO와 $\mathrm{MAO}$ 군에서 높았으며, $\mathrm{MAO}$ 군보다 $\mathrm{MHO}$ 군이 높았다 $(p<0.001)$. 그러나 $\mathrm{HDL}-\mathrm{C}$ 은 $\mathrm{MHNO}$ 군보다 $\mathrm{MHO}$ 와 $\mathrm{MAO}$ 군에서 낮았으 며, $\mathrm{MHO}$ 군보다 $\mathrm{MAO}$ 군이 낮았다 $(p<0.001)$. 또한 대사증후 군 위험요인인 높은 혈압, 낮은 $\mathrm{HDL}$-콜레스테롤혈증, 높은 공 복혈당, 복부비만, 고중성지방혈증의 발생빈도는 $\mathrm{MHNO}$ 군에 서 $\mathrm{MHO}$ 군, $\mathrm{MAO}$ 군으로 진행할수록 높은 빈도를 보였다(각각 $p<0.001)$.

\section{2. 대상자의 집단간 간 효소의 차이}

$\mathrm{MHNO}, \mathrm{MHO}, \mathrm{MAO}$ 군의 세 집단간 간 효소치의 차이를 비 교한 결과, $\mathrm{AST}$ 는 $\mathrm{MHNO}$ 군(26.28 \pm 13.87$)$ 보다 $\mathrm{MHO}$ 군

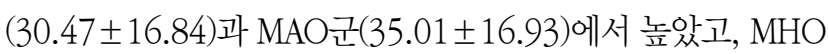
군보다 $\mathrm{MAO}$ 군이 통계적으로 유의하게 높았다 $(p<0.001)$ (Figure 1). $\mathrm{ALT}$ 는 $\mathrm{MHNO}$ 군(23.03 \pm 17.62$)$ 보다 $\mathrm{MHO}$ 군(35.61 \pm 29.69$)$ 과 $\mathrm{MAO}$ 군(43.77 \pm 29.02$)$ 에서 높았고, $\mathrm{MHO}$ 군보다 $\mathrm{MAO}$ 군이 유의하게 높았다 $(p<0.001)$ (Figure 2). GGT 또한 MHNO

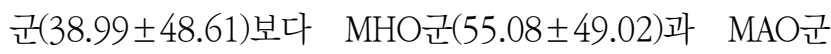
(74.45 \pm 65.03$)$ 이 높았고, $\mathrm{MHO}$ 군보다 $\mathrm{MAO}$ 군이 높았다 $(p<0.001)$ (Figure 3).

\section{3. 간 효소와 대사증후군 위험요인의 상관관계}

간 효소와 대사증후군 위험요인간의 상관성을 분석한 결과, $\mathrm{AST}$ 는 허리둘레 $(r=0.179, p<0.001)$, 수축기 $(r=0.120, p<0.001)$ 와 이완기혈압 $(r=0.129, p<0.001)$, 총콜레스테롤 $(r=0.111$, $p<0.001), \mathrm{LDL}-\mathrm{C}(r=0.081, p<0.001)$, 중성지방 $(r=0.128$, 
Table 1. Subjects clinical and biochemical characteristics of MHNO, MHO and MAO groups

\begin{tabular}{|c|c|c|c|c|}
\hline Variable & MHNO $(\mathrm{N}=2,878)$ & $\mathrm{MHO}(\mathrm{N}=5,427)$ & MAO $(N=1,378)$ & $p$-value \\
\hline Age (yr) & $44.65 \pm 11.54$ & $45.23 \pm 10.43$ & $48.29 \pm 10.85^{*, \dagger}$ & $<0.001$ \\
\hline Height $(\mathrm{cm})$ & $171.75 \pm 6.44$ & $171.28 \pm 6.38^{\star}$ & $171.78 \pm 6.39^{\dagger}$ & 0.001 \\
\hline Weight (kg) & $62.48 \pm 5.45$ & $78.18 \pm 8.08^{\star}$ & $83.44 \pm 9.97^{*, \dagger}$ & $<0.001$ \\
\hline $\mathrm{BMI}\left(\mathrm{kg} / \mathrm{m}^{2}\right)$ & $21.11 \pm 0.96$ & $26.65 \pm 2.02^{*}$ & $28.24 \pm 2.54^{*}+$ & $<0.001$ \\
\hline Waist circumference $(\mathrm{cm})$ & $76.17 \pm 4.71$ & $87.33 \pm 5.74^{*}$ & $93.36 \pm 5.89^{*},+$ & $<0.001$ \\
\hline Hip circumference $(\mathrm{cm})$ & $90.08 \pm 3.78$ & $97.72 \pm 4.48^{\star}$ & $100.46 \pm 5.20^{\star}{ }^{\dagger}$ & $<0.001$ \\
\hline Systolic BP (mmHg) & $108.45 \pm 11.90$ & $113.09 \pm 11.85^{*}$ & $123.39 \pm 14.56^{*} \dagger$ & $<0.001$ \\
\hline Diastolic BP (mmHg) & $69.80 \pm 9.05$ & $73.45 \pm 9.25^{\star}$ & $80.51 \pm 10.47^{*, \dagger}$ & $<0.001$ \\
\hline Total cholesterol (mg/dL) & $187.17 \pm 31.42$ & $199.15 \pm 34.58^{\star}$ & $201.05 \pm 37.03^{*}$ & $<0.001$ \\
\hline $\mathrm{HDL}-\mathrm{C}(\mathrm{mg} / \mathrm{dL})$ & $56.69 \pm 12.38$ & $50.41 \pm 10.48^{\star}$ & $43.75 \pm 10.01^{*, \dagger}$ & $<0.001$ \\
\hline $\mathrm{LDL}-\mathrm{C}(\mathrm{mg} / \mathrm{dL})$ & $114.00 \pm 28.18$ & $127.02 \pm 30.85^{\star}$ & $124.40 \pm 33.42^{*}$, & $<0.001$ \\
\hline Triglyceride (mg/dL) & $107.76 \pm 66.54$ & $147.66 \pm 88.24^{\star}$ & $242.09 \pm 119.24^{*, \dagger}$ & $<0.001$ \\
\hline Fasting glucose (mg/dL) & $87.97 \pm 17.76$ & $91.29 \pm 15.74^{\star}$ & $109.04 \pm 30.07^{*}+$ & $<0.001$ \\
\hline Uric acid (mg/dL) & $5.66 \pm 1.15$ & $6.25 \pm 1.28^{\star}$ & $6.40 \pm 1.44^{*}+$ & $<0.001$ \\
\hline $\mathrm{hs}-\mathrm{CRP}(\mathrm{mg} / \mathrm{dL})$ & $0.14 \pm 0.39$ & $0.17 \pm 0.40^{\star}$ & $0.21 \pm 0.50^{*}$, & $<0.001$ \\
\hline $\mathrm{HbA} 1 \mathrm{c}(\%)$ & $5.48 \pm 0.68$ & $5.61 \pm 0.63^{*}$ & $6.20 \pm 1.11^{*, \dagger}$ & $<0.001$ \\
\hline Insulin ( $\mathrm{uU} / \mathrm{mL})$ & $3.42 \pm 2.20$ & $5.84 \pm 3.14^{\star}$ & $8.13 \pm 4.08^{*}+$ & $<0.001$ \\
\hline HOMA-IR & $0.12 \pm 0.38$ & $0.23 \pm 0.60^{*}$ & $0.44 \pm 1.08^{*}, \dagger$ & $<0.001$ \\
\hline \multicolumn{5}{|l|}{ Metabolic syndrome risk factors } \\
\hline Waist circumference $\geq 90 \mathrm{~cm}^{\S}$ & $10(0.3)$ & $1551(28.6)$ & $1139(82.7)$ & $<0.001$ \\
\hline $\mathrm{BP} \geq 130 / 85 \mathrm{mmHg}^{\S}$ & $252(8.8)$ & $779(14.4)$ & $730(53.0)$ & $<0.001$ \\
\hline $\mathrm{HDL}-\mathrm{C}<40 \mathrm{mg} / \mathrm{dL}^{\S}$ & $160(5.6)$ & $586(10.6)$ & $628(45.6)$ & $<0.001$ \\
\hline Triglyceride $\geq 150 \mathrm{mg} / \mathrm{dL}^{\S}$ & $491(17.1)$ & $1945(35.8)$ & $1209(87.7)$ & $<0.001$ \\
\hline Fasting glucose $\geq 100 \mathrm{mg} / \mathrm{dL}^{\S}$ & $254(8.8)$ & $743(13.7)$ & $805(58.4)$ & $<0.001$ \\
\hline
\end{tabular}

Calculated by one way ANOVA and bonferroni test.

Values are presented as mean \pm SD.

*Significantly different from MHNO at $p<0.05,{ }^{\dagger}$ Significantly different from MHO at $p<0.05 .{ }^{\S}$ Calculated by $\chi^{2}$-test. Data are presented as number (\%).

Abbreviations: MHNO, metabolically healthy non obese; $\mathrm{MHO}$, metabolically healthy obese; MAO, metabolically abnormal obese; BMI, body mass index; BP, blood pressure; HDL-C, high density lipoprotein cholesterol; LDL-C, low density lipoprotein cholesterol; hs-CRP, high sensitivity C-reactive protein; HbA1c, hemoglobin A1c; HOMA-IR, homeostasis model assessment-insulin resistance.

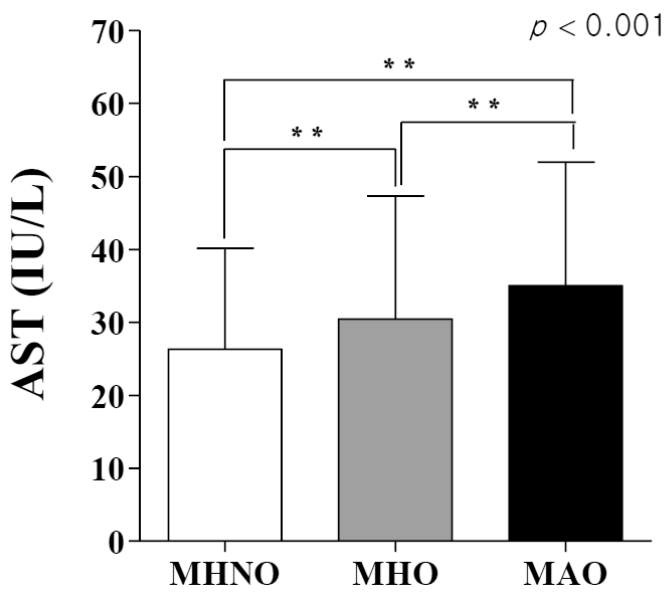

Figure 1. Difference of AST of MHNO, MHO, MAO groups. MHNO

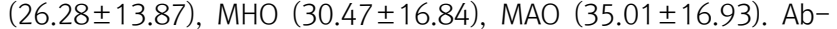
breviations: AST, aspartate aminotransferase; MHNO, metabolically healthy non obese; MHO, metabolically healthy obese; MAO, metabolically abnormal obese. ${ }^{* \star} p<0.001$.

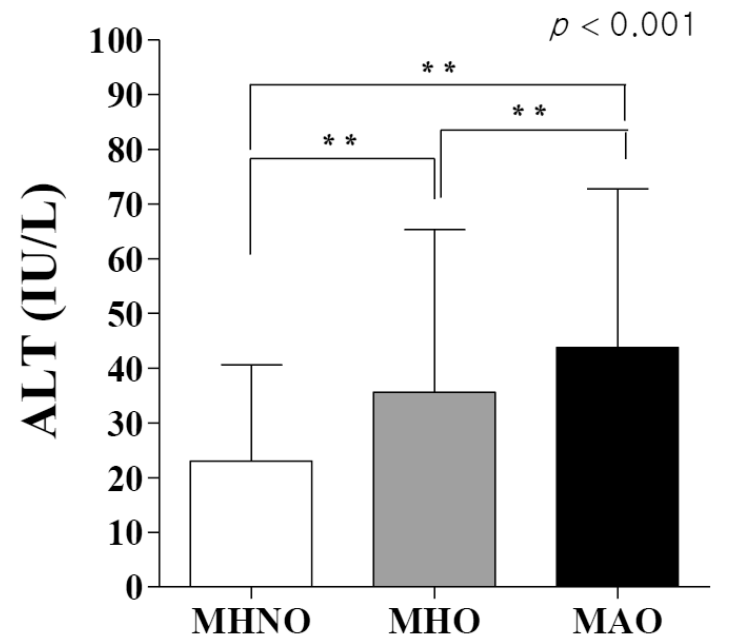

Figure 2. Difference of ALT of MHNO, MHO, MAO groups. MHNO (23.03 \pm 17.62$), \mathrm{MHO}(35.61 \pm 29.69), \mathrm{MAO}(43.77 \pm 29.02)$. Abbreviations: ALT, alanine aminotransferase; MHNO, metabolically healthy non obese; MHO, metabolically healthy obese; MAO, metabolically abnormal obese. ${ }^{* \star} p<0.001$. 
$p<0.001)$, 공복혈당 $(r=0.118, p<0.001)$ 과 통계적으로 유의 한양의 상관관계를 보였다. ALT는 허리둘레 $(r=0.266, p<0.001)$, 수축기 $(r=0.104, p<0.001)$ 와 이완기혈압 $(r=0.110, p<0.001)$, 총콜레스테롤 $(r=0.150, p<0.001), \mathrm{LDL}-\mathrm{C}(r=0.144, p<0.001)$, 중성지방 $(r=0.191, p<0.001)$, 공복혈당 $(r=0.125, p<0.001)$ 과는 유의한 양의 상관관계를 보였으며, $\mathrm{HDL}-\mathrm{C}(r=-0.149$, $p<0.001)$ 과는 음의 상관관계를 보였다. GGT와 허리둘레 $(r=0.215, p<0.001)$, 수축기 $(r=0.141, p<0.001)$ 와 이완기혈 압 $(r=0.144, p<0.001)$, 총콜레스테롤 $(r=0.178, p<0.001)$, $\mathrm{LDL}-\mathrm{C}(r=0.077, p<0.001)$, 중성지방 $(r=0.308, p<0.001)$, 공복혈당 $(r=0.192, p<0.001)$ 간에 유의한 양의 상관관계가 있 는 것으로 나타났다(Table 2).

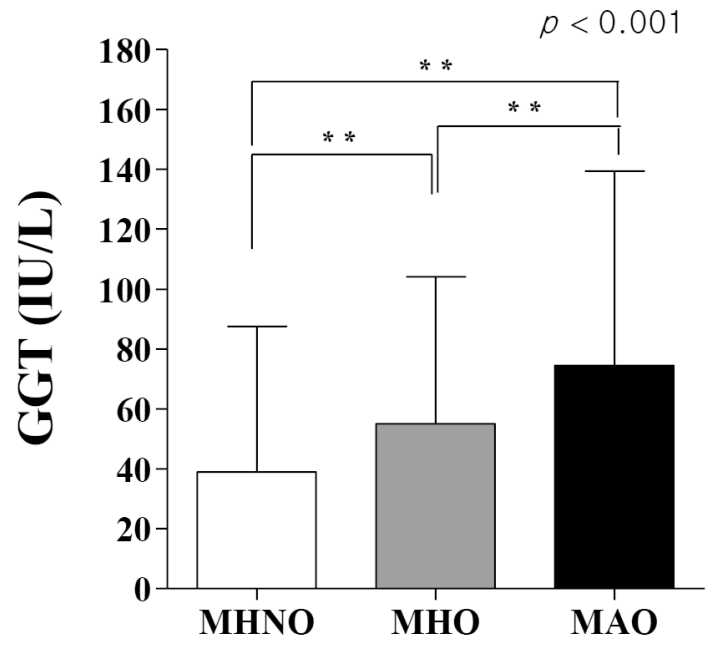

Figure 3. Difference of GGT of MHNO, MHO, MAO groups. MHNO

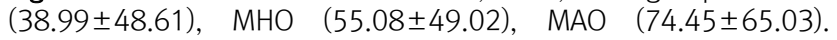
Abbreviations: GGT, gamma-glutamyl transferase; MHNO, metabolically healthy non obese; MHO, metabolically healthy obese; MAO, metabolically abnormal obese. ${ }^{\star \star} p<0.001$.

\section{4. 간 효소에 영향을 미치는 대사증후군 위험요인}

연령을 보정한 후 중다회귀분석을 실시하여 간 효소에 영향 을 미치는 대사증후군 위험요인을 예측한 결과, AST에 영향을 미치는 대사증후군 위험요인은 허리둘레 $(p<0.001)$, 이완기 혈 압 $(p=0.016)$, 공복혈당 $(p<0.001)$, 총콜레스테롤 $(p=0.001)$, 중성지방 $(p<0.001), \mathrm{HDL}-\mathrm{C}(p=0.013)$ 이었으며, 허리둘레가 $\mathrm{AST}$ 에 가장 영향을 미치는 요인이었다. ALT에는 허리둘레 $(p<0.001)$, 공복혈당 $(p<0.001)$, 총콜레스테롤 $(p<0.001)$, 중성지방 $(p=0.002), \mathrm{HDL}-\mathrm{C}(p<0.001)$ 이 영향을 미치는 요인 으로 나타났으며, 허리둘레가 ALT에 가장 영향을 미치는 요인 이었다. 또한 GGT에 영향을 미치는 대사증후군 위험요인은 허 리둘레 $(p<0.001)$, 공복혈당 $(p<0.001)$, 총콜레스테롤 $(p=0.010)$, 중성지방 $(p<0.001), \mathrm{HDL}-\mathrm{C}(p<0.001)$ 이었으며, 중성지방 은 GGT에 가장 영향을 미치는 요인으로 나타났다(Table 3).

\section{고 찰}

이 연구는 비만남성을 대상으로 대사적 이상 유무에 따라 $\mathrm{MHO}$ 와 $\mathrm{MAO}$ 군으로 분류하여 간 효소의 차이를 알아본 결과, $\mathrm{AST}, \mathrm{ALT}, \mathrm{GGT}$ 는 $\mathrm{MAO}$ 군보다 $\mathrm{MHO}$ 군에서 통계적으로 유의 하게 낮았다. 그러나 $\mathrm{MHO}$ 군은 $\mathrm{MHNO}$ 군보다는 간 효소치가 높게 나타났다. 또한 간 효소는 대사증후군 위험요인과 관련이 있으며, 허리둘레, 공복혈당, 총콜레스테롤, 중성지방, $\mathrm{HDL}-\mathrm{C}$ 은 AST, ALT, GGT에 영향을 미치는 위험요인으로 나타났다.

대사적으로 건강한 비만인(metabolically healthy obese, $\mathrm{MHO})$ 은 체질량지수로 평가하였을 때는 비만에 속하지만, 상 대적으로 인슐린 감수성이 높고 내장 비만도가 낮으며, 혈압이 나 지질대사 이상의 빈도가 낮아 대사적으로 건강한 상태를 일

Table 2. Correlation between metabolic syndrome risk factors and hepatic enzymes

\begin{tabular}{|c|c|c|c|c|c|c|}
\hline \multirow{2}{*}{ Variable } & \multicolumn{2}{|c|}{ AST (IU/L) } & \multicolumn{2}{|c|}{ ALT (IU/L) } & \multicolumn{2}{|c|}{ GGT (IU/L) } \\
\hline & $r$ & $p$ & $r$ & $p$ & $r$ & $p$ \\
\hline Waist circumference $(\mathrm{cm})$ & 0.179 & $<0.001$ & 0.266 & $<0.001$ & 0.215 & $<0.001$ \\
\hline Systolic BP (mmHg) & 0.120 & $<0.001$ & 0.104 & $<0.001$ & 0.141 & $<0.001$ \\
\hline Diastolic BP (mmHg) & 0.129 & $<0.001$ & 0.110 & $<0.001$ & 0.144 & $<0.001$ \\
\hline Total cholesterol (mg/dL) & 0.111 & $<0.001$ & 0.150 & $<0.001$ & 0.178 & $<0.001$ \\
\hline $\mathrm{HDL}-\mathrm{C}(\mathrm{mg} / \mathrm{dL})$ & -0.027 & 0.078 & -0.149 & $<0.001$ & 0.024 & 0.082 \\
\hline $\mathrm{LDL}-\mathrm{C}(\mathrm{mg} / \mathrm{dL})$ & 0.081 & $<0.001$ & 0.144 & $<0.001$ & 0.077 & $<0.001$ \\
\hline Triglyceride (mg/dL) & 0.128 & $<0.001$ & 0.191 & $<0.001$ & 0.308 & $<0.001$ \\
\hline Fasting glucose (mg/dL) & 0.118 & $<0.001$ & 0.125 & $<0.001$ & 0.192 & $<0.001$ \\
\hline
\end{tabular}

Calculated by Pearson correlation coefficient.

Abbreviations: AST, aspartate aminotransferase ALT, alanine aminotransferase; GGT, gamma-glutamyl transferase; BP, blood pressure; $\mathrm{HDL}-\mathrm{C}$, high density lipoprotein cholesterol; LDL-C, low density lipoprotein cholesterol. 
Table 3. Multivariate linear regression analysis: the association between the components of the metabolic syndrome with the hepatic enzymes

\begin{tabular}{|c|c|c|c|c|c|c|c|c|c|c|c|c|}
\hline \multirow{2}{*}{ Variable } & \multicolumn{4}{|c|}{ AST (IU/L) } & \multicolumn{4}{|c|}{ ALT (IU/L) } & \multicolumn{4}{|c|}{ GGT (IU/L) } \\
\hline & $B$ & SE & $\beta$ & $p$ & $B$ & SE & $\beta$ & $p$ & B & $S E$ & $\beta$ & $p$ \\
\hline Waist circumference $(\mathrm{cm})$ & 0.179 & 0.034 & 0.133 & $<0.001$ & 0.689 & 0.056 & 0.200 & $<0.001$ & 0.939 & 0.094 & 0.144 & $<0.001$ \\
\hline Systolic BP (mmHg) & 0.011 & 0.035 & 0.008 & 0.765 & 0.047 & 0.058 & 0.022 & 0.419 & 0.054 & 0.096 & 0.013 & 0.569 \\
\hline Diastolic BP (mmHg) & 0.109 & 0.045 & 0.068 & 0.016 & 0.078 & 0.074 & 0.029 & 0.290 & 0.215 & 0.123 & 0.041 & 0.081 \\
\hline Fasting glucose (mg/dL) & 0.058 & 0.012 & 0.074 & $<0.001$ & 0.116 & 0.020 & 0.087 & $<0.001$ & 0.298 & 0.035 & 0.114 & $<0.001$ \\
\hline Total cholesterol (mg/dL) & 0.027 & 0.008 & 0.056 & 0.001 & 0.079 & 0.013 & 0.098 & $<0.001$ & 0.054 & 0.021 & 0.035 & 0.010 \\
\hline Triglyceride (mg/dL) & 0.011 & 0.003 & 0.056 & $<0.001$ & 0.015 & 0.005 & 0.052 & 0.002 & 0.165 & 0.008 & 0.299 & $<0.001$ \\
\hline \multirow[t]{2}{*}{$\mathrm{HDL}-\mathrm{C}(\mathrm{mg} / \mathrm{dL})$} & 0.059 & 0.024 & 0.042 & 0.013 & -0.163 & 0.039 & -0.069 & $<0.001$ & 0.860 & 0.066 & 0.191 & $<0.001$ \\
\hline & \multicolumn{4}{|c|}{$\begin{array}{c}F=31.722^{* *}, R^{2}=0.055, \\
\text { Adj } R^{2}=0.053\end{array}$} & \multicolumn{4}{|c|}{$\begin{array}{c}F=75.304^{\star \star}, R^{2}=0.122 \\
\text { Adj } R^{2}=0.120\end{array}$} & \multicolumn{4}{|c|}{$\begin{array}{c}F=128.488^{* *}, R^{2}=0.163 \\
\text { Adj } R^{2}=0.162\end{array}$} \\
\hline
\end{tabular}

Calculated by multivariable linear regression analysis adjusted for age.

${ }^{* *} p<0.001$.

Abbreviations: AST, aspartate aminotransferase ALT, alanine aminotransferase; GGT, gamma-glutamyl transferase; BP, blood pressure; $\mathrm{HDL}-\mathrm{C}$, high density lipoprotein cholesterol.

컫는 비만의 하위유형이다[14]. Blüher [23]는 대부분의 비만 인에서 제 2 형 당뇨병, 고혈압, 이상지질혈증, 심혈관질환의 발 병위험과 인슐린 저항성이 증가하지만, 비만인 중 $10 ~ 25 \%$ 는 인슐린 감수성을 유지하며 대사이상의 빈도가 낮은 $\mathrm{MHO}$ 임을 보고하였다. 또한 비만의 효과적인 치료를 위해 대사적 이상 유 무에 따라 비만 환자를 계층화하는 것이 필요하다는 의견을 제 시하였다[23]. 한편, Calor 등[24]은 15년 동안 추적연구를 통 해 인슐린 저항성을 동반한 비만군과 달리 $\mathrm{MHO}$ 군은 전체사망 률, 암 및 심혈관질환에 의한 사망률이 증가하지 않았음을 보고 하였으며, Hamer와 Stamatakis [25]도 MHO군을 7년간 추적 조사한 결과 심혈관질환 및 전체 사망위험이 증가하지 않았다 고 보고하였다. 반면, $\mathrm{MHO}$ 는 $\mathrm{MHNO}$ 군과 비교할 때 제 2 형 당 뇨병과 같은 대사적 이상반응의 발생위험이 높으며, $\mathrm{MHO}$ 가 무 해한 상태를 의미하지는 않는다고 보고된다[26].

본 연구결과 $\mathrm{MHO}$ 군은 $\mathrm{MHNO}$ 군보다 허리둘레, 혈압, 지질 및 $\mathrm{HOMA}$ 지수가 높았으나, $\mathrm{MAO}$ 군보다는 낮게 나타났다. 또 한 대사증후군 위험요인의 발생률은 $\mathrm{MHO}$ 군이 $\mathrm{MHNO}$ 군보다 높은 빈도를 보였으나, $\mathrm{MAO}$ 군보다는 낮은 빈도를 보였다. Hong 등[27]의 연구에 의하면 $\mathrm{MHO}$ 는 $\mathrm{MAO}$ 군보다 허리둘레 가작으며, 인슐린 저항성 지수가 낮은 것으로 나타나 본 연구와 일치하는 결과를 보였다. 일반적으로 내장지방은 피하지방보 다 대사증후군 및 사망률과 밀접한 관련이 있는데[28], $\mathrm{MHO}$ 는 $\mathrm{MAO}$ 와 비교해 내장지방의 축적이 적은 특징을 보인다[17]. 이 소성 지방 축적은 간, 골격근, 췌장, 심근과 같은 비지방 조직에 지방이 축적되는 현상으로 장기에 손상을 줄 수 있으며, 내장지 방의 과다한 축적이 원인이다[10,11]. 이를 반영하는 결과로 Brochu 등[17]은 비만이더라도 $\mathrm{MHO}$ 는 $\mathrm{MAO}$ 보다 내장지방 함유량은 적지만 피하지방은 차이가 없다고 보고하였으며, 지
방간 평가에 있어서 $\mathrm{MHO}$ 는 $\mathrm{MAO}$ 보다 간의 지방 축적이 $54 \%$ 가량 적을 뿐 아니라 간 효소치도 낮다고 보고하였다[2,17].

본 연구결과 $\mathrm{AST}, \mathrm{ALT}, \mathrm{GGT}$ 치는 $\mathrm{MAO}$ 군보다 $\mathrm{MHO}$ 군이 낮 았으나, $\mathrm{MHNO}$ 군보다는 높았다. 또한 간 효소와 대사증후군 위험요인은 관련이 있으며, 허리둘레는 AST, ALT에 가장 영향 을 미치는 요인이었다. 선행연구에 따르면 간 효소인 AST, ALT, GGT의 높은 혈장 농도는 대사증후군, 인슐린 저항성 및 비알코 올 지방간질환(nonalcoholic fatty liver disease, NAFLD)과 관련이 있으며, 이러한 관련성은 제 2 형 당뇨병 및 심혈관계 질 환의 발병위험을 높이는 원인이 된다[29-32]. Messier 등[2]은 폐경 후 여성을 대상으로 $\mathrm{MHO}$ 군이 대사적 위험이 있는 비만군 보다 AST, ALT, GGT가 낮으며, 이는 MHO군에서 과도한 지질 침착을 특징으로 하는 NAFLD 발병위험이 낮음을 의미한다고 설명하였다[18]. $\mathrm{MHO}$ 에서 간의 지방 함유량이 낮은 것은 높은 유리지방산 산화율과 간세포에 지질침착 및 지방생성 저하에 의한 것이며[33], 인슐린 표적세포인 간에서 인슐린 저항성이 감소하는 결과로 나타난다[2]. 인슐린 표적세포인 간에서 인슐 린 저항성이 감소하는 결과로 나타난다[2]. 간 표지자와 당뇨병 간의 관련성에 인슐린 저항성이 매개체로 작용한다고 보고되었 으며[30], HOMA 지수로 평가한 인슐린 저항성이 대사적으로 위험군과 비교해 $\mathrm{MHO}$ 군에서 유의하게 낮은 결과를 보였다[2]. 본 연구에서도 $\mathrm{HOMA}$ 지수는 $\mathrm{MHO}$ 군이 $\mathrm{MAO}$ 군보다 낮았으나, $\mathrm{MHNO}$ 군보다는 높게 나타나 선행연구와 일치된 결과를 보였다.

본 연구결과를 뒷받침하는 이론으로 인슐린 작용과 혈당조 절을 관여하고 간에서 분비되는 헤파토카인(hepatokine)의 하 나인 fetuin-A는 인슐린 민감성 및 비만과 상관관계를 보이며, $\mathrm{MHO}$ 군에서 fetuin-A가 낮은 수치를 보여 $\mathrm{MHO}$ 군이 정상 체 중군보다 인슐린 저항성이 낮음을 구체적으로 증명하였다 
[34-36]. 그러나 Soriguer 등[37]은 $\mathrm{MHO}$ 군의 37\%가 6년 후에 $\mathrm{MAO}$ 로 전환된다고 보고하며, $\mathrm{MHO}$ 는 고정된 개념이 아니라 $\mathrm{MAO}$ 로 전환되는 과도기적 단계라고 주장하였다[38]. 본 연구 에서도 $\mathrm{MHNO}$ 군에서 $\mathrm{MHO}$ 와 $\mathrm{MAO}$ 군으로 진행할수록 $\mathrm{HOMA}$ 지수 및 대사증후군 위험과 간 효소치가 상승하는 것을 확인할 수 있었다. 그러므로 $\mathrm{MHO}$ 를 위험이 없는 군으로 간주할 것이 아니라 대사적으로 이상이 있는 $\mathrm{MAO}$ 군으로 이행하는 중간단 계로 잠재적 위험을 포함하고 있는 것으로 인식해야 할 것이다 [39,40]. MHO에 대한 다양한 평가기준으로 표준화된 진단기 준이 없음에도 불구하고 $[1,6,17,21]$, 본 연구는 $\mathrm{MHO}$ 와 관련된 잠재적인 위험요인 및 간 효소와의 관련성을 확인함으로써 대 사적으로 건강한 비만에 대한 조기 진단과 예방에 도움이 될 것 으로 생각된다.

결론적으로 $\mathrm{MHO}$ 군은 $\mathrm{MAO}$ 군과 비교해 간 효소와 대사증후 군 위험요인 발생빈도의 감소를 보였으며, 간 효소는 대사증후 군 위험요인과 관련이 있는 것으로 나타났다. 또한 대사적으로 이상이 있는 비만군뿐만 아니라 대사적으로 건강한 비만남성에 서간 효소가 대사적 이상을 예측할 수 있는 지표인 것을 확인하 였으나, 후속연구로 대사적 이상을 예측할 수 있는 간 효소치의 절단값에 관한 연구가 요구된다. 이러한 결과를 통해 대사적으 로 건강한 비만남성이 대사적으로 이상이 있는 비만군으로 진 행하는 것을 예방하는 방법으로 대사적 위험을 감소시키는 신 체활동이 필요하리라 사료된다[41].

\section{요 약}

대사적으로 건강한 비만인(metabolically healthy obese, $\mathrm{MHO}$ )은 대사적 합병증을 동반하지 않으며, 과도한 체지방에 도 불구하고 인슐린 감수성을 유지하는 비만의 표현형이다. 이 연구는 20세 이상 70세 이하의 남성을 대상으로 비만과 대사적 이상 유무에 따라 $\mathrm{MHNO}, \mathrm{MHO}$ 와 $\mathrm{MAO}$ 군으로 분류하여 간 효 소의 차이를 알아보고 대사적으로 건강한 비만남성에서 간 효 소가 대사적 이상을 예측할 수 있는 지표인지 그 임상적 의의를 확인하고자 하였다. Executive Summary of The Third Report of The National Cholesterol Education Program Adult Treatment Panel III (NCEP-ATP III) 진단기준으로 대사적 이 상을 평가하였으며, 비만 진단기준은 $\mathrm{WHO}$ 에서 제시하는 아시 아인의 기준을 따라 세 군으로 분류하였다. 최종 연구 대상자 9,683명 중 대사적으로 건강한 정상체중군(metabolically healthy non obese, MHNO) 2,878명, 대사적으로 건강한 비 만군(metabolically healthy obese, $\mathrm{MHO}$ ) 5,427명, 대사적으
로 이상이 있는 비만군(metabolically abnormal obese, $\mathrm{MAO}$ ) 1,378 명 이었다. AST, ALT, GGT는 MAO군보다 $\mathrm{MHO}$ 군에서 통계적으로 유의하게 낮았으나(각각 $p<0.001), \mathrm{MHO}$ 군은 $\mathrm{MHNO}$ 군보다는 간 효소치가 높게 나타났다(각각 $p<0.001$ ). 또한 간 효소는 대사증후군 위험요인과 관련이 있으며, 허리둘 레, 공복혈당, 총콜레스테롤, 중성지방, HDL-C은 AST, ALT, GGT에 영향을 미치는 위험요인으로 나타났다. 결론적으로 대 사적으로 건강한 비만남성에서 간 효소가 대사적 이상을 예측 할 수 있는 지표인 것을 확인하였다.

\section{Acknowledgements: None}

Funding: None

Conflict of interest: None

\section{REFERENCES}

1. Karelis AD, Brochu M, Rabasa-Lhoret R. Can we identify metabolically healthy but obese individuals (MHO)? Diabetes Metab. 2004;30(6):569-572.

2. Messier V, Karelis AD, Robillard ME, Bellefeuille P, Brochu M, Lavoie JM, et al. Metabolically healthy but obese individuals: relationship with hepatic enzymes. Metabolism. 2010;59(1): 20-24.

3. Messier V, Karelis AD, Prud'homme D, Primeau V, Brochu M, Rabasa-Lhoret R. Identifying metabolically healthy but obese individuals in sedentary postmenopausal women. Obesity (Silver Spring). 2010;18(5):911-917.

4. Karelis AD, Faraj M, Bastard JP, St-Pierre DH, Brochu M, Prud'homme D, et al. The metabolically healthy but obese individual presents a favorable inflammation profile. J Clin Endocrinol Metab. 2005;90(7):4145-4150.

5. Shea JL, King MT, Yi Y, Gulliver W, Sun G. Body fat percentage is associated with cardiometabolic dysregulation in BMI-defined normal weight subjects. Nutr Metab Cardiovasc Dis. 2012;22(9):741-747.

6. Wildman RP, Muntner P, Reynolds K, McGinn AP, Rajpathak S, Wylie-Rosett J, et al. The obese without cardiometabolic risk factor clustering and the normal weight with cardiometabolic risk factor clustering: prevalence and correlates of 2 phenotypes among the US population (NHANES 1999-2004). Arch Intern Med. 2008;168(15):1617-1624.

7. Peppard PE, Young T, Palta M, Dempsey J, Skatrud J. Longitudinal study of moderate weight change and sleep-disordered breathing. JAMA. 2000;284(23):3015-3021.

8. Sowers M. Epidemiology of risk factors for osteoarthritis: systemic factors. Curr Opin Rheumatol. 2001;13(5):447-451.

9. Frezza EE, Wachtel MS, Chiriva-Internati M. Influence of obesity on the risk of developing colon cancer. Gut. 2006;55(2): 285-291.

10. Stefan N, Kantartzis K, Machann J, Schick F, Thamer C, Rittig K, 
et al. Identification and characterization of metabolically benign obesity in humans. Arch Intern Med. 2008;168(15): 1609-1616.

11. D'Adamo E, Cali AM, Weiss R, Santoro N, Pierpont B, Northrup $\mathrm{V}$, et al. Central role of fatty liver in the pathogenesis of insulin resistance in obese adolescents. Diabetes Care. 2010;33(8): 1817-1822.

12. Flegal KM, Kit BK, Orpana H, Graubard BI. Association of all-cause mortality with overweight and obesity using standard body mass index categories: a systematic review and metaanalysis. JAMA. 2013;309(1):71-82.

13. Beleigoli AM, Boersma E, Diniz Mde F, Lima-Costa MF, Ribeiro AL. Overweight and class I obesity are associated with lower 10-year risk of mortality in Brazilian older adults: the Bambuí Cohort Study of Ageing. PLoS One. 2012;7(12):e52111.

14. Primeau V, Coderre L, Karelis AD, Brochu M, Lavoie ME, Messier V, et al. Characterizing the profile of obese patients who are metabolically healthy. Int J Obes (Lond). 2011;35(7): 971-981.

15. Meigs JB, Wilson PW, Fox CS, Vasan RS, Nathan DM, Sullivan LM, et al. Body mass index, metabolic syndrome, and risk of type 2 diabetes or cardiovascular disease. J Clin Endocrinol Metab. 2006;91(8):2906-2912.

16. Lee K. Metabolically obese but normal weight (MONW) and metabolically healthy but obese (MHO) phenotypes in Koreans: characteristics and health behaviors. Asia Pac J Clin Nutr. 2009;18(2):280-284.

17. Brochu M, Tchernof A, Dionne IJ, Sites CK, Eltabbakh GH, Sims EA, et al. What are the physical characteristics associated with a normal metabolic profile despite a high level of obesity in postmenopausal women? J Clin Endocrinol Metab. 2001;86(3): 1020-1025.

18. Mulhall BP, Ong JP, Younossi ZM. Non-alcoholic fatty liver disease: an overview. J Gastroenterol Hepatol. 2002;17(11):1136-1143.

19. Expert Panel on Detection, Evaluation, and Treatment of High Blood Cholesterol in Adults. Executive summary of the third report of the national cholesterol education program (NCEP) expert panel on detection, evaluation, and treatment of high blood cholesterol in adults (Adult Treatment Panel III). JAMA. 2001;285(19):2486-2497.

20. World Health Organization. The Asia-Pacific Perspective: Redefining obesity and its treatment. Sydney, Australia: Health Communications Australia; 2000. p19-20.

21. Lynch LA, O'Connell JM, Kwasnik AK, Cawood TJ, O'Farrelly C, O'Shea DB. Are natural killer cells protecting the metabolically healthy obese patient? Obesity (Silver Spring). 2009;17(3):601605.

22. Moon K, Sung SH, Chang YK, Park IK, Paek YM, Kim SG, et al. The association between Apolipoprotein E genotype and lipid profiles in healthy woman workers. J Prev Med Public Health. 2010;43(3):213-221.

23. Blüher M. The distinction of metabolically 'healthy' from 'unhealthy' obese individuals. Curr Opin Lipidol. 2010;21(1):38- 43.

24. Calori G, Lattuada G, Piemonti L, Garancini MP, Ragogna F, Villa $\mathrm{M}$, et al. Prevalence, metabolic features, and prognosis of metabolically healthy obese Italian individuals: the Cremona Study. Diabetes Care. 2011;34(1):210-215.
25. Hamer M, Stamatakis E. Metabolically healthy obesity and risk of all-cause and cardiovascular disease mortality. J Clin Endocrinol Metab. 2012;97(7):2482-2488.

26. Bell JA, Kivimaki M, Hamer M. Metabolically healthy obesity and risk of incident type 2 diabetes: a meta-analysis of prospective cohort studies. Obes Rev. 2014;15(6):504-515.

27. Hong HC, Lee JS, Choi HY, Yang SJ, Yoo HJ, Seo JA, et al. Liver enzymes and vitamin D levels in metabolically healthy but obese individuals: Korean National Health and Nutrition Examination Survey. Metabolism. 2013;62(9):1305-1312.

28. Ibrahim MM. Subcutaneous and visceral adipose tissue: structural and functional differences. Obes Rev. 2010;11(1):11-18.

29. Hanley AJ, Williams K, Festa A, Wagenknecht LE, D'Agostino RB Jr, Haffner SM. Liver markers and development of the metabolic syndrome: the insulin resistance atherosclerosis study. Diabetes. 2005;54(11):3140-3147.

30. Hanley AJ, Williams K, Festa A, Wagenknecht LE, D'Agostino RB Jr, Kempf J, et al. Elevations in markers of liver injury and risk of type 2 diabetes: the insulin resistance atherosclerosis study. Diabetes. 2004;53(10):2623-2632.

31. Stefan N, Kantartzis K, Häring HU. Causes and metabolic consequences of fatty liver. Endocr Rev. 2008;29(7):939-960.

32. Thamer C, Tschritter O, Haap M, Shirkavand F, Machann J, Fritsche A, et al. Elevated serum GGT concentrations predict reduced insulin sensitivity and increased intrahepatic lipids. Horm Metab Res. 2005;37(4):246-251.

33. Frayn KN. Adipose tissue as a buffer for daily lipid flux. Diabetologia. 2002;45(9):1201-1210.

34. Mathews ST, Singh GP, Ranalletta M, Cintron VJ, Qiang X, Goustin AS, et al. Improved insulin sensitivity and resistance to weight gain in mice null for the Ahsg gene. Diabetes. 2002; 51(8):2450-2458.

35. Ix JH, Wassel CL, Kanaya AM, Vittinghoff E, Johnson KC, Koster A, et al. Fetuin-A and incident diabetes mellitus in older persons. JAMA. 2008;300(2):182-188.

36. Stefan N, Hennige AM, Staiger H, Machann J, Schick F, Kröber $\mathrm{SM}$, et al. Alpha2-Heremans-Schmid glycoprotein/fetuin-A is associated with insulin resistance and fat accumulation in the liver in humans. Diabetes Care. 2006;29(4):853-857.

37. Soriguer F, Gutiérrez-Repiso C, Rubio-Martín E, GarcíaFuentes E, Almaraz MC, Colomo N, et al. Metabolically healthy but obese, a matter of time? Findings from the prospective Pizarra study. J Clin Endocrinol Metab. 2013;98(6):2318-2325.

38. Appleton SL, Seaborn CJ, Visvanathan R, Hill CL, Gill TK, Taylor AW, et al. Diabetes and cardiovascular disease outcomes in the metabolically healthy obese phenotype: a cohort study. Diabetes Care. 2013;36(8):2388-2394.

39. Yoo HJ. Pathogenesis and clinical implications of metabolically healthy obesity (MHO) and metabolically obese normal weight (MONW) subjects. J Korean Diabetes. 2014;15(1):12-16.

40. Hong SB, Shin KA, Choi WS. Comparison of echocardiogram and clinical profile between metabolically healthy obese (MHO) and non metabolically healthy obese (Non-MHO) subjects. J Exp Biomed Sci. 2012;18(3):260-267.

41. Velho S, Paccaud F, Waeber G, Vollenweider P, Marques-Vidal P. Metabolically healthy obesity: different prevalences using different criteria. Eur J Clin Nutr. 2010;64(10):1043-1051. 